\title{
Measuring Disparities in Non-School Costs and Revenue Capacity among Massachusetts Cities and Towns
}

\author{
Katharine Bradbury and Bo Zhao
}

\begin{abstract}
This paper develops new measures of environmental costs and local revenue capacity as the basis for a new municipal aid formula in Massachusetts. On the cost side, unlike previous studies, we quantify the effects on local non-school spending of characteristics related to uncontrollable costs. On the capacity side, we account for the constraints of a tax limitation, for the first time in the literature, by estimating these constraints as a function of residents' incomes. The estimates of costs and capacity indicate substantial inter-local fiscal disparities in Massachusetts. Our approach is potentially applicable to other states.
\end{abstract}

JEL Classifications: H70, H71, H72, H73, H77, H83, H20

Keywords: fiscal disparities, municipal costs, revenue capacity, property tax, state aid, tax limitation

Katharine Bradbury is a senior economist and policy advisor in the Research Department and Bo Zhao is an economist in the New England Public Policy Center, both at the Federal Reserve Bank of Boston. Their email addresses are katharine.bradbury@bos.frb.org and bo.zhao@bos.frb.org, respectively.

The authors acknowledge excellent research assistance from Jessamyn Fleming, Matthew Nagowski, Antoniya Owens, and Ashley Provencher and very useful discussions with their colleagues on the "research team" of the Municipal Aid Subcommittee of the Municipal Finance Task Force: Alan Clayton-Matthews, Chris Giuliani, Cam Huff, and Pam Kocher. They have benefited from participation in meetings of the Municipal Aid Subcommittee of the Municipal Finance Task Force. They are also grateful to Shihe Fu, Tracy Gordon, Andrew Hanson, Katherine Kiel, Donald Marples, John Yinger, and participants at the National Tax Association's 2006 fall conference, the Rappaport Institute's Boston 101 seminar, and the New England Study Group seminar for very helpful comments.

This paper, which may be revised, is available on the web site of the Federal Reserve Bank of Boston at http://www.bos.frb.org/economic/wp/index.htm.

The views expressed in this paper are solely those of the authors and are not those of the Federal Reserve System or the Federal Reserve Bank of Boston.

This version: May 4, 2007 


\section{Introduction}

Massachusetts cities and towns are seeking additional non-school aid from the state government. Partly because increases in state aid were concentrated on public schools during the 1990s and partly because state budget cuts during recent economic downturns have reduced non-school aid and generally made it unpredictable, cities and towns are under considerable fiscal strain. In the last few years, many communities have instituted layoffs and cut services, and many have raised property taxes (see Municipal Finance Task Force, 2005 and Bluestone, Clayton-Matthews, and Soule, 2006).

The very local character of city and town government makes Massachusetts particularly prone to substantial inter-jurisdictional fiscal disparities, and also makes state aid virtually the only mechanism capable of addressing them. According to Yinger (1986), "fiscal disparities exist when some cities can provide a given level of local public services at lower cost or at less sacrifice than can other cities." In Massachusetts, residents are served by 351 mutually exclusive and exhaustive cities and towns. Each municipality is responsible for the entire range of standard local services, including schools, police and fire protection, public works, human services, libraries and recreation, etc. As other research indicates and as we show below, both the environment in which these services are produced and the resources available to finance them vary markedly across municipalities in ways that affect the cost or tax burden involved in providing a standard quantity and quality of services. The resulting fiscal disparities across municipalities lead to inequity and inefficiency, which are mostly outside the control of local governments (Yinger, 1986). Previous research suggests that higher levels of government may be able to improve social welfare through intergovernmental grants (for example, Bradbury et al., 1984 and Yinger, 1986). For these reasons, Massachusetts state government has a history of providing general-purpose aid, in addition to earmarked school aid.

Because the two existing municipal aid formulas do not respond appropriately to communities' current needs, a new aid formula is needed to distribute any potential increase in non-school aid. The cost-based aid formula introduced in the mid-1980s has not functioned 
properly since the early 1990s, ${ }^{1}$ and the formula that allocates the only other substantial municipal aid (lottery aid) is not comprehensive, mainly because it does not consider cost differentials across communities, but also because it considers only property values in measuring local resources. This paper reports on research underpinning the development of a new non-school municipal aid formula for Massachusetts cities and towns. Formulas to allocate local aid in most states-whether for schools or for general municipal purposes-typically distribute funds in inverse proportion to each jurisdiction's ability to raise revenue locally (that is, local revenue capacity) and/or in proportion to its needs or costs. ${ }^{2}$ The revenue capacity side of the calculation typically takes account of the size of the tax bases that local governments are authorized to tap. The cost/need side is generally extremely simple or ad hoc, often using population alone (or enrollment in the case of school aid) to represent need. Our research develops new measures of both elements to reflect more accurately the realities and constraints of local government in Massachusetts.

On the cost side, unlike previous studies of either total spending or school spending, our research focuses on non-school spending. Following Bradbury et al. (1984), Yinger (1988a, 1988b), Ladd and Yinger (1989), and Ladd, Reschovsky, and Yinger (1991), ${ }^{3}$ we use regression analysis and recent data to quantify the relationship between local non-school spending and environmental cost proxies that are outside the control of local governments, such as population density and commuters per capita. Because we focus on non-school spending while cities and

1 The cost-based aid formula introduced in the mid-1980s included schools in its cost and capacity measures. The formula was used to calculate total aid in proportion to the difference between costs and capacity, then school aid was calculated according to a separate formula, and "Additional Assistance" was the residual (municipal) aid. As school aid expanded over time and Additional Assistance funds grew slowly and then declined in real terms, the interactive operation of the two formulas implied that school aid addressed the need-revenue gaps of many communities, eliminating their entitlement to general municipal aid (Additional Assistance).

2 The terms "costs" and "needs" (or "expenditure needs") are sometimes used interchangeably. For example, Bradbury et al. (1984) report that "[uncontrollable] cost disparities produce what some people have referred to as variations in service 'needs'." (p. 152); Ladd and Yinger (1989) combine cost indexes for police, fire, and general services into a measure of "standardized expenditure need."

3 The research reported in Bradbury et al. (1984) formed the basis of the cost-based local aid formula enacted in the mid-1980s in Massachusetts. Ladd, Reschovsky, and Yinger (1991) laid out the foundation for a later, cost-based formula for Minnesota. 
towns in Massachusetts are responsible for local public schools, our regressions must also control for the role of public schools in "draining" resources that might otherwise be available for non-school spending, in addition to controlling for available resources and preference indicators.

On the revenue capacity side, our research focuses on accounting for the constraints of a tax limitation, for the first time in the literature. We incorporate the effects of Proposition $2 \frac{1 / 2}{2}$ the local property tax limitation in Massachusetts - in our measure of local revenue capacity. Proposition $2 \frac{1}{2}$ caps property tax rates and limits the year-to-year growth in property tax revenues of each city and town, but allows local voters to override the growth limits. The existing lottery aid formula distributes aid in inverse proportion to communities' per capita property tax bases, but many local officials argue that this is unfair, since Proposition $2^{1 / 2}$ differentially limits individual cities' and towns' ability to tap into their property tax base. On the other hand, Proposition $2^{1 / 2} 2^{\prime} s$ annual levy limits cannot be treated as exogenous binding constraints because local voters can, and in many communities do, override them. Our research uses data on recent taxing patterns to develop a measure of the effects of the constraints on local property taxation-a measure not in the control of local officials or local voters-and uses that measure to adjust the size of the local property tax base in measuring revenue capacity. In addition, our measure of revenue capacity takes account of the ability to raise revenue from other (non-property-tax) local sources and subtracts the capacity not available for general municipal (non-school) purposes.

The difference between these measures of municipal costs and capacity for each community - the fiscal "gap" - is intended to provide the basis for a new aid formula that channels more aid to communities with larger gaps. For such a purpose, the measures of costs and capacity must be predetermined-not in the immediate control of local governments; otherwise, the formula would reward communities that are inefficient or put less effort into raising revenue, and would create incentives for local officials to change behavior in ways that increase the amount of aid-by adding to measured costs or reducing measured capacity. This search for predetermined-and still relevant-indicators is a critical challenge in measuring both costs and capacity. 


\section{Non-School Cost Differentials}

Local jurisdictions differ in what it costs them, per capita, to provide a standard quality and quantity of municipal services; some of these differences are attributable to the efficiency of the production process they choose to adopt and some are attributable to factors in their environment that are outside their control. One example of the latter, uncontrollable, environmental costs is that a community with more jobs per capita has to spend more on services for commuters and employers, such as traffic lights, plowing, road maintenance, and police protection. Similarly, per capita firefighting costs might differ across communities, depending on population density. In the context of a median voter model, Bradbury et al. (1984) and Yinger (1986) show how environmental costs affect the production function and the expenditure function for local services.

One question that arises when there are many geographically small local governments, as in Massachusetts, is whether the potential mobility of a community's residents in response to fiscal disparities makes local "cost" characteristics endogenous (Oakland, 1994). Such reverse causation resulting from "Tiebout sorting" seems unlikely to be an important factor in the current context for several reasons. First, a migration response to disparities in non-school services and taxes seems much less likely than for schools, which account for over half of city and town spending and the location response to which has been well documented (for example, see Bradbury, Case, and Mayer, 1998). Second, Yinger (1986) shows that mobility between adjacent communities and migration among urban areas-even with their associated housing price adjustments - do not eliminate fiscal disparities, including those related to environmental cost differences. Finally, even if some location responses do occur, it is still the case that at any point in time, environmental costs are outside the control of local governments. That is, longerrun economic endogeneity does not invalidate the estimates of "cost" impacts if the factors are predetermined in the medium term from the point of view of local officials.

Following Bradbury et al. (1984), Yinger (1988a, 1988b), Ladd and Yinger (1989), and Ladd, Reschovsky, and Yinger (1991), this paper adopts a regression-based approach to measuring uncontrollable cost differentials across cities and towns in Massachusetts. Citing Bradford, Malt, and Oates (1969), the earlier research argues that spending on local public 
services in any municipality reflects three factors: (1) the service responsibilities of the local jurisdiction, (2) the choices made by city or town officials and residents about service quality, and (3) the cost per unit of service quality that the community faces. Service responsibilities (factor 1) do not vary across Massachusetts communities because cities and towns are responsible for financing all local public services, as school districts are dependent on cities and towns for revenue, and county governments are now defunct (and never had much responsibility). We control for service quality (factor 2) by including variables measuring local preferences and resources, which are the key determinants of local service quality choices. With factor 1 constant and factor 2 controlled for, our regressions attempt to estimate the effect of environmental costs (factor 3) on "standard" local spending. ${ }^{4}$

In a departure from previous studies of either total spending or school spending, we limit the dependent variable to non-school spending in order to develop a measure of nonschool costs for use in a municipal (non-school) aid formula. We also add to the control variables an exogenous measure of the potential drain on resources represented by a community's responsibility to provide public schools: ${ }^{5}$ the number of school-age children per capita in the community. ${ }^{6}$ The dependent variable is defined in per capita terms as all nonschool city and town spending from the general fund (thus excluding spending from enterprise

${ }^{4}$ Like other researchers, we have no data to control directly for the efficiency of production processes that local governments choose in supplying local services. However, there is no reason to believe that such choices are correlated with our cost variables (or other included variables) and hence biasing those estimated coefficients.

${ }^{5}$ If public school districts in Massachusetts were independent entities with the ability to raise revenue on their own, their tax take could simply be subtracted from local resources (as in Ladd and Yinger, 1989). But city councils and town meetings vote on school budgets as well as on public safety budgets, and almost all the funds, aside from aid, come from the city or town's property tax levy.

${ }^{6}$ We also tried some alternative proxies for school responsibilities: measures of public school enrollment per capita, foundation budget per capita, school operating costs per capita, and the net minimum required local contribution per capita. The foundation budget-constructed by the Massachusetts Department of Education as a function of student characteristics-can be seen as a cost index for each school district; the net minimum required local contribution is set by the Massachusetts Department of Education and indicates the minimum public school dollars that must be paid out of local (property tax) resources, not out of school aid. In all these cases, the regression results were very similar to those reported in Table 2. 
funds), with two adjustments. ${ }^{7}$ One adjustment removes all reported public works spending on water, sewer, and solid waste disposal; most municipalities operate their water, sewer, and solid waste disposal services via enterprise funds, but some do not, so removing this category of expenditures makes the spending data more consistent across all communities. ${ }^{8}$ The second adjustment removes intergovernmental spending and adds back spending on employee health insurance, which some communities failed to include in their "Schedule A" reports; as with public works, this adjustment aims to make the spending figures more comparable across communities. ${ }^{9}$ However, some communities with a fully or partially local school district report their local-school-related debt service and benefits costs (for example, teachers' health insurance) in "debt service" and "fixed cost" spending categories of Schedule A, and it is not possible to separate out this detailed sub-category. In an attempt to remove the effects of localschool-related debt service and benefits costs, the regressions also include dummy variables for fully or partially regional school districts (with the omitted category being fully local school

7 These data are published by the Massachusetts Department of Revenue, based on a year-end financial report (Schedule A) submitted to the Division of Local Services (DLS) by city and town officials. The general fund accounts for most financial resources and activities and is governed by town meeting or city council appropriation processes. An enterprise fund is a separate accounting and financial reporting mechanism for municipal services for which a fee is charged in exchange for goods or services. Lisa Juszkiewicz of DLS provided invaluable assistance in helping us understand how the published data define and report various measures and in supplying more detailed data for some concepts that allowed us to make the two adjustments noted in the text.

8 Removing spending on water, sewer, garbage, and trash improves consistency not only for these accounting reasons but also because the level of services that is publicly provided varies more for these services than most. Municipalities in urban areas tend to provide public water, sewer, and solid waste disposal services, while residents of more open suburbs and rural areas generally have wells and septic systems and take their own solid waste to local landfills, so less of this type of service is provided publicly. If these categories were not removed, the spending variable would include more publicly provided services in dense urban areas than elsewhere and the coefficients on the cost factors might incorrectly capture some of this as costs rather than service levels. The fact that open suburban and rural communities remove these costs from the public sector and push them directly onto their residents does not make these communities less deserving of aid.

${ }_{9}^{9}$ Excluding intergovernmental spending serves two purposes: (1) it removes the school spending of cities and towns that are members of regional school districts in a manner similar to our exclusion of the school spending category for communities that have local schools; (2) it removes payments to other entities that provide services to the municipality, such as the MBTA and other regional transit authorities, which we treat instead as reductions in capacity (that is, as potential local resources not available to fund general municipal services). 
districts - the category into which over half the communities fall). ${ }^{10}$ We expect the signs on the two dummy variables to be negative, reflecting the lower measured municipal spending on benefits and debt of towns with separate regional school districts. The dependent variable is adjusted per capita non-school spending averaged over three fiscal years (FY2000-FY2002); the averaging is intended to smooth year-to-year fluctuations in order to obtain coefficients that reflect more stable, longer-term relationships.

The earlier research of Bradbury et al. (1984) and Ladd and Yinger (1989) suggests a variety of indicators of environmental, uncontrollable municipal costs for inclusion. Thus, the initial variable list includes population density, density squared, population size, a measure of the number of commuters (private employment per capita by place of work-measured where jobs are located, not where job-holders live), ${ }^{11}$ the fraction of the housing stock that is older rental units, the fraction of the housing stock that is owner-occupied, the fraction of the housing stock that is single-family, a private-sector wage index, the unemployment rate, the rate of population growth or decline, the fraction of the population that is foreign-born, the fraction of the population that is 65 and older, and the number of miles of road per capita. However, because the estimated coefficients on the cost variables are to be used to compute a cost index for the distribution of aid, cost variables with estimated coefficients not significantly different from zero are deleted from the final regression. ${ }^{12}$ Table 1 reports summary statistics for the

10 The choice of regional versus local school provision is correlated with population size and density for obvious reasons. This correlation implies that our estimated coefficients on these cost variables may be biased downward when we include the regional school dummies - that is, our cost estimates may be conservative; however, if we excluded them, the coefficients could be biased upward. We also tried categorizing "mixed school" communities by how many grades were local versus regional; the estimated cost coefficients in the regression with more-detailed school variables are very similar to those reported in Table 2 .

${ }^{11}$ In the estimating equation, only private-sector employment is included. Government employment includes the city or town government's own employees, as well as employment of other government entities located in the municipality; the data do not allow us to separate these two elements of government employment. Thus if total employment were included as an exogenous variable in the spending regression, any inefficiency of cities and towns taking the form of hiring more than the costeffective number of workers could bias the coefficient upward compared with true "uncontrollable" costs associated with commuters.

12 This contrasts with the approach we would use in a research report or academic article, where we would report all the estimated coefficients and their standard errors. 
variables included in the final spending regressions.

For ease of interpretation, a simple linear specification is used to explain per capita nonschool spending. ${ }^{13}$ In order to reduce noise and achieve a better fit for the model, the equation is estimated on the 320 cities and towns in Massachusetts having a population greater than 1,000 in the year 2000, other than Provincetown. ${ }^{14}$ Most explanatory variables are measured as of the year 2000. The regression results for adjusted per capita non-school spending are shown in column (1) of Table 2, including estimated coefficients and "robust" (Huber-White sandwich) estimates of standard errors. The estimated coefficients on cost factors indicate that communities with greater density, larger population size, more jobs per capita, and higher poverty and unemployment rates have to pay more per capita to provide a standard bundle of municipal services, that is, these communities face a harsher environment for public production of non-school services. For example, a city or town with private employment about equal to population - near the top of the range-would face per capita costs for municipal services about \$175 higher than communities in which private job counts amount to only about one-fifth of the local resident population (around the $35^{\text {th }}$ percentile). As noted earlier, by design (selection), the cost coefficients are all significantly different from zero with at least 95-percent confidence.

The estimated coefficients on most control variables also have the expected signs and are statistically significant. For example, both property values and income have strong positive effects on spending, presumably reflecting the important role of resources and preferences in

${ }^{13}$ Some researchers express per capita spending in logarithmic form, others use the linear form; in our case, the signs and statistical significance and hence the resulting list of key cost factors are similar in the two versions.

${ }^{14}$ Provincetown is dropped from the sample because its 2000 unemployment rate is extreme - it is twice as high as that of the second highest community in the state; its inclusion causes a very sizable change in the estimated unemployment coefficient. 
local budgeting. ${ }^{15}$ The estimated coefficient on school-age children per capita, however, is not significantly different from zero and has a positive sign, which seems counterintuitive. As discussed in more detail below, this control variable has the expected negative effect on most subcategories of non-school spending.

Because cities and towns (or the decisive voters in cities and towns) presumably respond to higher costs - just as they would to any higher price-by cutting back on consumption, highcost communities will have slightly lower demand for public services than preference and resource factors alone would predict (Bradbury et al., 1984, Downes and Pogue, 1994, and Oakland, 1994). ${ }^{16}$ That is, the cost coefficients we estimate are likely to be underestimates of the full effect of environmental factors on costs. ${ }^{17}$

Columns (2) through (5) of Table 2 report coefficient estimates on the final set of cost variables for a mutually exclusive and exhaustive set of subcategories of local non-school spending: public safety; adjusted public works; general government, health, welfare, culture, and recreation; and adjusted debt service, fixed cost, and other. Because the sum of these spending subcategories equals total non-school spending and the equations are linear and include all the same variables, the coefficients on each variable sum across spending subcategories to equal the corresponding coefficient in column (1). These disaggregated results indicate that commuters and workplaces increase the per capita costs of providing all types of local government services. Larger population size is associated with higher per capita costs for

${ }^{15}$ In an alternative version (not shown), we included per capita net non-school aid as an additional resource variable; its estimated coefficient was not significantly different from zero, and estimated coefficients on other included variables were very similar to those reported in Table 2. Data limitations prevent us from investigating potential effects of school aid on non-school spending because aid to regional school districts cannot be correctly attributed to member cities and towns. In another alternative version, we added tax price-measured as median house value divided by the per capita property tax base-to the equation; the coefficient on tax price was not significantly different from zero, and the other coefficients were almost identical to those shown in Table 2.

${ }^{16}$ While standardized test scores are sometimes used as measures of education output (see, for example, Downes and Pogue, 1994), final outputs of most non-school public services cannot be directly observed or accurately measured; otherwise we would regress cost factors on final outputs, instead of local spending, to avoid the potential underestimation.

17 Inman (1979) estimates that these price elasticities are fairly low, however, around -0.3. 
public safety and adjusted debt service-fixed cost-other, but with lower per capita costs for adjusted public works. Local per capita spending on general government services (including health, welfare, culture, and recreation), adjusted public works, and adjusted debt service-fixed cost-other increases with the poverty rate. Both higher density and a higher unemployment rate raise the per capita costs of public safety and of general government services.

Among the control variables, the effect of having (partially and fully) regional schools is concentrated in the adjusted debt service-fixed cost-other category, as expected. Furthermore, the coefficient on school-age children per capita in this equation is positive, presumably because local-school-related costs contribute to this spending category (in addition to the amount that the regional school dummy variables account for). By contrast, in the equations for public safety, adjusted public works, and general government services, school-age children per capita obtains a negative coefficient, possibly reflecting the drain of school demands in reducing funds available for these municipal services. All told, the coefficient on school-age children per capita in the total spending equation-the sum of the effects on the subcategories of spending-is positive but statistically indistinguishable from zero.

We calculate the cost measure, costi, for each community $i$, as

$$
\operatorname{cost}_{i}=\alpha+\sum_{j}\left(\beta_{j} \cdot X_{i j}\right),
$$

where $X_{i j}$ is the value of cost factor $j$ in community $i, \beta_{j}$ is the estimated coefficient on cost factor $j$ from column (1) of Table 2 , and $\alpha$ is a constant chosen so that $\cos _{k}$ is equal to average per capita non-school spending when $k$ indexes the hypothetical community with average values 
for the cost factors. ${ }^{18}$ Calculated in this way, the cost measure can be interpreted as an estimate of the per capita spending required for a community with $i$ 's characteristics to provide standard local non-school services at average efficiency.

In 2000 , the cost measure ranges from just under $\$ 500$ to over $\$ 1,500$, and averages $\$ 799$. To show how different characteristics translate into estimated cost variations, we construct several example cities and towns, which we call "prototype communities." The upper panel of Appendix Table A1 displays the values of cost variables and estimated costs for five prototypes-large city, rural town, job-center suburb, higher-income residential suburb, and resort town-based on data for several actual cities and towns we believe exemplify each descriptive label. Prototype Communities A (large city) and C (job-center suburb) face high costs of producing municipal services, with above-average population density and large population size, combined with either high poverty and unemployment (large city) or substantial job concentrations (job-center suburb). By contrast, costs are considerably lower in Prototype Communities B (rural town) and D (higher-income residential suburb), with lower density, less poverty, and fewer jobs and hence commuters.

Figure 1 maps estimated non-school costs of individual cities and towns, categorized by quintiles. The highest cost communities (darkest shade) have per capita costs over $\$ 884$, while costs for the lowest quintile communities (palest shade) are below $\$ 692$ per capita. The prototypes and map make clear that inter-local cost differentials are considerable and represent

${ }^{18}$ We make one adjustment to this procedure. We multiply total employment per capita in town i by the estimated coefficient on private employment per capita. This adjustment represents a compromise between (1) our desire as researchers to avoid biasing the coefficient estimate if inefficient communities have more local public employees-hence we exclude government employees from the estimating equation-and (2) local officials' desires to include the costs imposed on individual communities by commuters employed by federal, state, and local governments-hence we include government employees in the cost calculation. This adjustment is made under the assumption that the marginal effect of public employment on uncontrollable spending is the same as that of private employment. An alternative approach would be to include total employment in the regression but treat it as endogenous, with private employment as the instrument. When we did this, the estimated employment coefficient was slightly lower than what is shown in Table 2, and the other cost coefficients were also changed very little. Because we hope that our approach to estimating the coefficients and measuring non-school costs will eventually be adopted by the Commonwealth, we opted for the simpler, easier-to-explain, non-IV approach. 
an important element of fiscal disparities that a state aid formula should consider.

\section{Local Revenue Capacity}

Local revenue capacity is defined as the ability of local governments to raise revenues from their own resources. It should therefore reflect resources local governments could tax, not actual revenues raised, since local governments can choose to tax local resources at different rates. In addition to the relative wealth of resources that local governments can tap, a measure of capacity should also reflect external constraints on ability to tap those resources, such as tax limitations or outright prohibition of specific revenue sources. The Advisory Commission on Intergovernmental Relations (ACIR) developed an approach to measuring revenue capacity called the "Representative Revenue System (RRS)" (ACIR, 1962, 1971, and 1986). RRS assigns a standard tax rate to each tax base of all local or state governments, so that the measured revenue capacity from taxes is strictly proportional to the size of the tax bases and does not depend upon how heavily they are actually taxed. This approach is widely used in measuring local revenue capacity, in particular, as there are usually no institutional differences among local jurisdictions within a state, which would make inter-community comparisons difficult.

Property taxes are often the largest source of local revenues. In most states' local aid formulas-including the lottery aid formula in Massachusetts-property tax capacity is measured as a constant proportion of the property tax base using a standard RRS approach. An important assumption underlying this approach is that all cities and towns can tap into their property tax base to the same degree. However, this assumption may not hold in states with local property tax limitations. If cities and towns face differential impacts of local tax limitations, then they are able to tap into their property tax base only to varying degrees. In a survey of existing general-purpose local aid formulas of the 50 states conducted in the spring of 2006, we find that none incorporate the constraints of local tax limitations in their measures of local revenue capacity.

Proposition 21/2, enacted by referendum in 1980, limits local property taxes in Massachusetts in two ways (Massachusetts Department of Revenue, 2005): (1) in the first three years after its enactment, it brought all municipalities' property tax rates down to $2 \frac{1}{2}$ percent of 
the estimated market value of their property tax bases and permanently capped them at $2^{1 / 2}$ percent (this rate limit is called the "levy ceiling"), which voters are prohibited from overriding, except temporarily via capital or debt exclusions; and (2) it sets a "levy limit" - a limit on the annual property tax levy (that is, total property tax revenues) - that rises by only $2 \frac{1}{2}$ percent per year plus an allowance for taxes on any value added to the tax base by new construction and substantial renovation ("new growth").

The $2 \frac{1}{2}$-percent tax-rate ceiling was binding in the early years of Proposition 21/2, but its importance has significantly decreased as a result of substantial growth in property values. By contrast, limits on levy growth remain important for many cities and towns in Massachusetts, with FY2006 levies in almost half of the 351 cities and towns within 0.1 percent of their levy limits, and over two-thirds within 1 percent. ${ }^{19}$

The simplest approach to incorporating Proposition $2 \frac{1}{2} 2^{\prime} \mathrm{s}$ constraints into a measure of property tax capacity would seem to be to set the capacity measure equal to the levy limit-the amount of property taxes a community is allowed to collect. However, local voters may choose to override Proposition $2 \frac{1}{2} 2^{\prime} \mathrm{s}$ constraints on year-to-year revenue growth by voting to increase the local levy limit. Votes to override the growth limit raise the levy limit permanently, adding to the base to which the next year's automatic $2 \frac{1}{2}$ percent growth rate is applied. Faced with limits on levy growth, some communities manage to propose and pass overrides, loosening the constraints, while others do not; some local governments, perhaps believing that they have no chance of passing an override, have never put one on the ballot. Thus, the levy limit, which appears at first blush to be an exogenous binding constraint, is not exogenous, and because of these differential impacts of Proposition $2 \frac{1}{2}$, the ability of cities and towns to tap into their property tax base varies.

Bradbury (1991) and Reschovsky and Schwartz (1992) find that Massachusetts communities with lower per capita incomes are less likely to propose overrides than those with

\footnotetext{
${ }^{19}$ Consistent with the pattern observed in Massachusetts, Figlio (1997) and Mullins and Wallin (2004) suggest that limits on revenue growth are more likely to bind local governments than are ceilings on the tax rate.
} 
higher incomes, other things being equal. Bradbury's analysis finds an even larger effect of income on the probability that an override will pass. In addition, Mullins (2004) shows that local tax limitations constrain most stringently the ability of local governments to raise revenue in low-income communities across the nation. These pieces of empirical evidence suggest that the ability of cities and towns to tap into their property tax base under a limitation like Proposition $2 \frac{1}{2}$ may increase with income. Therefore, we investigate the relationship between income and property taxes across Massachusetts cities and towns in 2000 in order to judge whether income might proxy for the ability of individual communities to tap into their property tax bases after operating under the constraints of Proposition 21/2 for almost 20 years. If so, since income (like the property tax base itself) is predetermined from the point of view of each local government at any point in time, it could be used to adjust the size of the local property tax base in measuring (constrained) property tax capacity. ${ }^{20}$

We use regression analysis of data on municipalities' taxing patterns in 2000 to quantify the effects of Proposition $2 \frac{1 / 2}{2}$ and develop a new measure of property tax capacity. Because it is local residents who vote and the income level of local residents that matters in passing an override, we measure revenue capacity from residential and open space (residential, for short) property and from commercial, industrial, and personal (CIP) property separately. We assume that residential property tax capacity (residential capacity, for short) is determined by the interaction of the residential property tax base and the ability of local governments to tap into that tax base, which we model as a function of residents' incomes. Under these assumptions, we estimate a model,

$$
\begin{aligned}
\log (\text { residential property tax levy } i)= & \alpha_{0}+\alpha_{1} \log \left(\text { residential property value }_{i}\right) \\
& +\alpha_{2} \log \left(\text { income }_{i}\right)+\varepsilon_{i},
\end{aligned}
$$

where the variables are expressed in per capita terms and are subscripted for municipality $i$; $\varepsilon_{i}$ is

\footnotetext{
${ }^{20}$ One might question the exogeneity of either the income or the property tax base because households and businesses may choose to locate in cities and towns with the local property tax rates that they prefer. As argued earlier regarding environmental costs, while Tiebout sorting may occur in the long run, at any point in time, the size of the property tax base and residents' incomes - and hence a community's ability to raise revenue-are outside the control of and therefore predetermined from the point of view of each local government's decision-makers.
} 
the residual. The log-log functional form allows for potential nonlinearity in the relationships. As in the cost regressions, we use a sub-sample comprising 321 cities and towns with population larger than 1,000 in the year $2000 .{ }^{21}$ Summary statistics for the variables are reported in Table 3.

Akin (1973), Ladd (1975), and Tannenwald, Perrault, and Wattenberg (1987) also run regressions of revenue on various tax bases and income. However, they consider income as an underlying tax base and interpret the estimated coefficients on income and property values as weights of the tax bases in measuring revenue capacity. By contrast, our approach uses income to represent the constraints of Proposition 21/2, not a tax base.

As shown in the first column of Table 4, the estimated coefficients on log income per capita and log per capita residential value are positive and highly significant. A positive coefficient on income is consistent with the hypothesis that the ability of local governments to tap into their residential property tax base increases with residents' income. ${ }^{22}$ Estimated regressions shown in the remaining columns of Table 4 address several potential biases and find that column (1)'s baseline results are quite robust. First, because income is often used as a proxy variable for community residents' preferences or tastes, the estimated coefficient on income in the baseline model may capture some taste or preference variations, not just the constraints of Proposition 21/2. To explore this issue, we add a standard set of control variables for preferences and tastes in the regression reported in column (2); almost all of these control variables are significantly correlated with income. But the estimated coefficients on income and property value in the new regression are not significantly different-statistically or economically - from the baseline results. Second, we add cost variables as proxies for the local environment, along with the preference and taste variables. The augmented regression shown in column (3) yields coefficient estimates even closer to the baseline results.

\footnotetext{
${ }^{21}$ When we run the same regressions using data for all 351 cities and towns, the results are very similar to those reported in Table 4, but the R-squared is smaller.

${ }^{22}$ In addition to being reflected in the coefficient on the income variable, some constraints of Proposition $2 \frac{1}{2}$ may be reflected in the fact that the coefficient on log per capita residential value is less than one. That is, residential value does not translate proportionally into residential capacity even in a community with average income.
} 
Third, the composition of the property tax base may explain some variations in the residential property tax levy because municipalities with higher CIP property value may have less need to raise revenue from residential property than municipalities with lower CIP property value. When we add log per capita CIP value to the baseline model (column (4)), the coefficients of interest on income and residential property value are again quite similar to those in column (1). Fourth, extreme incomes in a community may significantly influence average income but not the median. To test the robustness of our results to different measures of income, we replace per capita income with median household income and run the property tax levy regression in per-household terms. The estimated relationships among residential levy, residential tax base, and income shown in column (5) are almost the same as in the baseline model. Last, there are some municipalities, mostly on Cape Cod and the Islands, that have extraordinarily high per capita residential property values and roughly average per capita incomes. To avoid potential bias from these "outliers," we drop these municipalities from the sample for column (6). The results are not statistically different from the baseline results.

Some local officials argue that our estimated results might not reflect the variations in taxing ability that result from Proposition $2 \frac{1}{2} 2$, but rather variations in reliance on property tax revenue that result from an inverse relationship between income and state aid. In fact, the relationship between income and state aid has evolved opposite to this presumption since the early 1980s. The Municipal Finance Task Force (2005; Table 2.8, p. 43) reports that municipalities in the highest-income quintile received the largest increase in net local aid between 1992 and 2002 and the second largest increase for the longer period of 1981 to 2004. In addition, Reschovsky and Schwartz (1992) show that the probability of proposing a property tax override does not depend upon state aid.

Using the baseline estimates, we construct a measure of residential property tax capacity that reflects the constraints of Proposition 21/2. Because the baseline coefficient estimates are very close to two-thirds and one-third, we use those figures for simplicity. Through a simple transformation, we can express residential capacity as

$$
\text { residential capacity } i=\tau_{1} \bullet \text { residential value }_{i}{ }^{\frac{2}{3}} \bullet \text { income }_{i}{ }^{\frac{1}{3}},
$$


where $\tau_{1}$ is a statewide constant, and all the variables are expressed in per capita terms. Under the assumption that a city or town with average characteristics taxes its residential property at its full capacity - that is, the per capita residential capacity of this "average" city or town is equal to the average per capita residential property tax levy, $\tau_{1}$ can be calculated as the statewide average per capita residential property tax levy divided by the product of the statewide average per capita residential value raised to a power of two-thirds, and the statewide average income per capita raised to a power of one-third. In 2000, $\tau_{1}$ is equal to 0.0175 . According to the measure, a municipality with an average per capita residential property tax base and per capita income 10 percent above the statewide average has an estimated per capita residential capacity 3.2 percent above average, all other things being equal. Moreover, a municipality with average per capita income and per capita residential property value 10 percent above the statewide average possesses an estimated per capita residential capacity 6.6 percent above average.

We use the standard RRS approach to measure tax capacity from CIP property, calculating capacity as a constant proportion of CIP value. ${ }^{23}$ In per capita terms,

$$
\text { CIP } \text { capacity } i=\tau_{2} \bullet \mathrm{CIP} \text { value }_{i}
$$

where $\tau_{2}$ is a statewide constant. Under the (standard RRS) assumption that an average city or town taxes its CIP property at its full capacity, $\tau_{2}$ can be calculated as the statewide average per capita CIP tax levy divided by the statewide average per capita CIP value. In $2000, \tau_{2}$ is equal to 0.0142 .

In addition to property taxes, local governments in Massachusetts can raise revenues

${ }^{23}$ When we investigate whether to use income in calculating CIP capacity in a manner parallel to residential capacity, we find the relationship between per capita CIP levy and per capita income to be negative, controlling for per capita CIP value; that is, a given CIP value yields more property tax revenue in a low-income community than in a high-income community. These estimates reflect the fact that Massachusetts cities and towns can choose to tax CIP property at a higher rate than residential property in order to shift some of the tax burden from local residents to business taxpayers. In 2000, 100 communities had split property tax rates and they were generally communities with below-average incomes. Thus, the negative relationship between CIP levy and income reflects poor communities' decisions to shift the tax burden to business property, rather than a negative effect of income on ability to raise revenue. Since the relationship reflects endogenous local decision-making, it would be inappropriate to include income in the measure of CIP capacity. 
from selected other local sources, although they are not allowed to tax other broad bases. Just as for the property tax, measures of other revenue capacity should capture the underlying ability of a local government to raise revenue from these sources, but not individual communities' choices about tax rates, local option taxes, etc. Our measure includes capacity from the motor vehicle excise, local option hotel-motel excise, urban redevelopment excise, local share of state racing taxes, and state government payments in lieu of taxes for state-owned land (mostly forests). ${ }^{24}$

Capacity to raise revenue from the local option hotel-motel excise is an interesting example. Data are available on the size of the tax base only for those communities that have opted to levy the tax. We estimate the average per capita hotel-motel tax capacity-potential revenues at a standardized tax rate- of other communities using information on whether or not a community has any hotel-motel establishments and data on the total tax base in these nonlocal-option communities (the statewide tax base minus the tax base in all local-option communities).

Not all local revenue capacity is available for general municipal purposes. Local governments face other demands, most notably for public schools, that draw on local revenue bases. Therefore, we subtract from local revenue capacity the capacity that is "used up" by nonmunicipal purposes, which we call "statutorily required reductions in capacity." These reductions are either required contributions or payments for services provided by other entities, ${ }^{25}$ they do not reflect local governments' choices or behavior.

Because of maintenance-of-effort provisions in the school aid formula, the Massachusetts Department of Education calculates a "required local contribution"-dollars to

\footnotetext{
${ }^{24}$ We do not consider any type of state aid as part of local capacity because it is not drawn from local sources. Because existing state aid is not included in the calculation of capacity and hence the costcapacity gap, its treatment when designing a distribution formula for new aid is an important and complex issue. As mentioned briefly in Section III below, discussing methods of distributing aidformula design -is beyond the scope of this paper.

25 These reductions in capacity are the equivalent of the revenues removed from a city's capacity by overlying governments, as analyzed by Ladd and Yinger (1989) in comparing the fiscal capacity of large cities nationwide. Massachusetts, however, has no local governments other than cities and towns, and no entities other than state government and cities and towns with the power to levy taxes.
} 
be raised through municipal property taxes - that each city or town must make to its local and/or regional public schools. ${ }^{26}$ These required local contributions comprise the largest reduction in capacity. Other reductions include county taxes, charges for regional transit, regional planning authorities, and state assessments for air pollution and mosquito control.

Finally, we calculate total non-school local revenue capacity as the sum of residential property tax capacity, CIP property tax capacity, and other local revenue capacity, minus statutorily required reductions in capacity. In 2000, per capita total non-school local revenue capacity for an average city or town was $\$ 677$. As the lower panel of Appendix Table A1 shows, Prototype Communities A (large city) and B (rural town) have very limited revenue capacity, with small per capita property tax bases, low incomes, and modest capacity from other revenue sources. Prototype Communities C (job-center suburb) and D (higher-income residential suburb) have greater local revenue-raising capacity, both from property taxes and from other local sources, while also having considerably greater revenue responsibility for schools, which uses up some local capacity. ${ }^{27}$ Prototype Community E (resort town) has even larger residential property values per resident, mostly in the form of vacation homes owned by nonresidents, and larger CIP value per resident, combined with more modest residents' incomes. ${ }^{28}$ These prototypes and the quintile cutoffs reported in Figure 2 show significant variation across Massachusetts cities and towns in per capita non-school local revenue capacity in 2000.

\section{Fiscal Gap and Issues in Aid Formula Design}

To calculate the per capita gap for each community, net per capita local revenue capacity is subtracted from estimated per capita costs. The relative size of the gap represents the degree

\footnotetext{
${ }^{26}$ A community's required local contribution for schools is a function of the foundation spending level, year-to-year growth in local revenues, and state school aid, but does not reflect actual local school spending decisions.

27 The state provides less school aid and requires communities like these to make a greater local contribution to schools on account of their higher property values and income.

28 One outcome of using our measure of residential property tax capacity-which takes account of residents' incomes - is that communities like Prototype E have lower measured residential property tax capacity than they would using a simple RRS capacity measure that is proportional only to the size of their residential property tax base.
} 
of mismatch for cities and towns between their costs of a standard bundle of municipal services and their ability to raise revenue from local sources for municipal purposes. As the bottom row of Appendix Table A1 shows, the per capita non-school cost-capacity gap for a city or town with average characteristics in Massachusetts was \$122 in 2000. The distribution ranges from large negative gaps-for example, as shown for the resort town prototype (Community E), which has a very large property tax base-to substantial positive gaps, as shown for the large city prototype (Community A), with high costs and low capacity. ${ }^{29}$ In between, Prototype Community D (higher-income residential suburb) has moderate costs and relatively high capacity, yielding a smaller negative gap, while Prototype Communities B and C have gaps larger than that of the average community, but for different reasons-Community B (rural town) has moderate costs and very low capacity while Community C (job-center suburb) has high costs and slightly below-average capacity. Overall, we estimate substantial inter-local disparities across Massachusetts cities and towns among per capita non-school gaps (Figure 3).

It is important to update the measures of costs, capacity, and gap periodically so that the aid calculation in each year is based on accurate, current information. Because of the way we calculate these measures, there are two update-related issues. First, the values of the cost and capacity factors that enter into the gap calculations for each community should be updated annually, because they may change from year to year and the data for most factors are available on an annual basis. When the values of the factors are updated, the statewide constants in the cost and capacity calculations (that is, $\alpha, \tau_{1}$, and $\tau_{2}$ ) would also be updated to retain the equality between average spending or tax levy in that year and the calculated costs or capacity for the community with average factor values. Second, by contrast, the estimated coefficients in the cost and capacity regressions do not need to be updated often, because the underlying relationships are not likely to change rapidly over time. A practical approach would be to re-estimate them every 10 years when decennial census data become available.

${ }^{29}$ One might ask why people stay in high-cost, low-capacity cities and towns. Yinger (1986) shows that it is more likely for the poor to live in high-cost, low-capacity areas because they are outbid by the wealthy for housing in low-cost, high-capacity municipalities. He also points out that racial and ethnic discrimination and restrictive zoning may play a role in constraining the mobility of poor households. 
As noted earlier, using a gap-based approach to local aid involves designing a formula that would distribute aid in proportion to measured gaps across communities. With "aid proportional to gap" as the basic approach, however, a number of issues would need to be resolved in developing a specific aid formula. Two such issues relate to (1) the "baseline" gap above which aid would be distributed proportionally and (2) whether there should be a (nonzero) per capita floor on aid dollars for communities with gaps lower than that baseline gap. While we believe that the gap calculation outlined in this paper provides a sound basis for measuring the relative fiscal disadvantage of communities, its zero point has very little or no absolute normative meaning and should not be regarded as a natural baseline gap. Thus, decisions about both the baseline gap and aid floor are policy choices. Another issue is "hold harmless;" for lottery aid, school aid, and most other local aid distributions, Massachusetts has a history of retaining the previous year's aid dollars for all communities and running the formula only to allocate the new aid dollars added that year. Finally, a new aid formula would need to consider how to treat existing general-purpose municipal aid funds, which are not counted as part of revenue capacity in the gap calculation. All of these implementation issues deserve further research.

\section{Conclusion}

This paper develops new measures of locally uncontrollable costs and local revenue capacity for potential use in a new, general-purpose aid formula for Massachusetts cities and towns. On the cost side, we focus on local non-school spending, quantifying the effects of uncontrollable-cost-related characteristics while controlling for the impacts of school responsibilities, available resources, and preferences. We find that communities with greater population density, number of commuters, population size, unemployment, and poverty have to spend more per capita to provide a standard bundle of municipal services; that is, they have higher uncontrollable costs.

On the revenue capacity side, we focus on accounting for the constraints of a tax limitation. We utilize data on recent taxing patterns to develop a measure of the effective constraints of Proposition $2 \frac{1}{2}$ that is exogenous from the perspective of local officials and use 
that measure to adjust the size of the local property tax base in measuring revenue capacity. Modeling the constraints as a function of residents' incomes, we find that local governments in higher-income communities have greater ability to tap into their residential property tax base and thus are less constrained by the local property tax limitation. Our capacity measure also takes account of each community's ability to raise revenue from other (non-property-tax) local sources and subtracts the local revenue capacity not available for general municipal (nonschool) purposes.

We measure the fiscal "gap" for each community as the difference between its locally uncontrollable costs and its local revenue capacity. Such measurements indicate that Massachusetts cities and towns vary widely in the degree of mismatch between their costs and capacity. A new municipal aid formula that distributes per capita aid in proportion to measured per capita gaps across communities would help to alleviate these substantial inter-local fiscal disparities. Such a gap-based approach would provide more aid to cities and towns with higher uncontrollable costs and lower ability to raise revenue locally, other things being equal.

Our measurement approach is designed for Massachusetts but potentially applicable to other states facing similar challenges. Like Massachusetts, many other states have been "reforming" their approach to education finance, resulting in significant increases in school aid; the "No Child Left Behind Act" has increased the incentive for states to concentrate aid on schools. School aid, however, often crowds out general-purpose municipal (non-school) aid in state budgets. Moreover, during the recent recession, some states, such as Michigan and Minnesota - and Massachusetts - froze or cut general-purpose local aid. Thus, policymakers in other states may see general-purpose aid as an important issue, and our approach could be useful to them. If one were cognizant of institutional idiosyncrasies, it would be fairly easy to replicate our method using other states' data. On the cost side, only Minnesota (to our knowledge) currently incorporates a measure of exogenous cost differences into its non-school aid formula. On the local revenue capacity side, 42 other states have local tax limitations and none have incorporated the constraints of tax limitations in their aid formulas (Mullins and Wallin, 2004). Adapting our approach to measuring both uncontrollable costs and revenue capacity could help these states to develop more fair aid distributions. 


\section{References}

Advisory Commission on Intergovernmental Relations. 1962. Measures of State and Local Fiscal Capacity and Tax Effort: A Staff Report. Washington, D.C.: U.S. Government Printing Office.

Advisory Commission on Intergovernmental Relations. 1971. Measuring the Fiscal Capacity and Effort of State and Local Areas. Washington, D.C.: U.S. Government Printing Office.

Advisory Commission on Intergovernmental Relations. 1986. Measuring State Fiscal Capacity: Alternative Methods and Their Uses. Washington, D.C.: U.S. Government Printing Office.

Akin, John S. 1973. "Fiscal Capacity and the Estimation Method of the Advisory Commission on Intergovernmental Relations." National Tax Journal 26:2 (June), 275-293.

Bluestone, Barry, Alan Clayton-Matthews, and David Soule. 2006. Revenue Sharing and the Future of Massachusetts Economy. <http://www.curp.neu.edu/pdfs/MMA_RevenueSharing.pdf>

Bradbury, Katharine L., Helen F. Ladd, Mark Perrault, Andrew Reschovsky, and John Yinger. 1984. "State Aid to Offset Fiscal Disparities Across Communities." National Tax Journal 37:2 (June), 151-170.

Bradbury, Katharine L. 1991. “Can Local Governments Give Citizens What They Want? Referendum Outcomes in Massachusetts." New England Economic Review (May/June), 322.

Bradbury, Katharine L, Karl E. Case, and Christopher J. Mayer. 1998. "School Quality and Massachusetts Enrollment Shifts in the Context of Tax Limitations." New England Economic Review (July/August), 3-20.

Bradford, David F., R. A. Malt, and Wallace E. Oates. 1969. “The Rising Cost of Local Public Services: Some Evidence and Reflections." National Tax Journal 22:2 (June), 185-202.

Downes, Thomas A. and Thomas F. Pogue. 1994. “Adjusting School Aid Formulas for the Higher Cost of Educating Disadvantaged Students." National Tax Journal 47:1 (March), 89-110.

Figlio, David N. 1997. “Did the 'Tax Revolt' Reduce School Performance?" Journal of Public Economics vol. 65, 245-269.

Inman, Robert P. 1979. “The Fiscal Performance of Local Governments: An Interpretive Review," in Peter Mieszkowski and Mahlon Straszheim, eds., Current Issues in Urban Economics. Baltimore: The Johns Hopkins University Press. 
Ladd, Helen F. 1975. "Local Education Expenditures, Fiscal Capacity, and The Composition of the Property Tax Base." National Tax Journal 28:2 (June), 145-160.

Ladd, Helen F. and John Yinger. 1989. America's Ailing Cities: Fiscal Health and the Design of Urban Policy. Baltimore and London: The Johns Hopkins University Press.

Ladd, Helen F., Andrew Reschovsky, and John Yinger. 1991. Measuring the Fiscal Condition of Cities in Minnesota. Report submitted to the Legislative Commission on Planning and Fiscal Policy (April).

Massachusetts Department of Revenue. Revised 2005. Levy Limits: A Primer on Proposition 21/2. < http://www.dls.state.ma.us/PUBL/MISC/levylimits.pdf>

Mullins, Daniel R. 2004. "Tax and Expenditure Limitations and the Fiscal Response of Local Government: Asymmetric Intra-Local Fiscal Effects." Public Budgeting and Finance (Winter), 111-147.

Mullins, Daniel R. and Bruce A. Wallin. 2004. "Tax and Expenditure Limitations: Introduction and Overview." Public Budgeting and Finance (Winter), 2-15.

Municipal Finance Task Force. 2005. Local Communities at Risk: Revisiting the Fiscal Partnership Between the Commonwealth and Cities and Towns. <http://www.mapc.org/Municipal_Finance_Task_Force/Executive\%20Summary.pdf>

Oakland, William H. 1994. “Fiscal Equalization: An Empty Box?” National Tax Journal 47:1 (March), 199-209.

Reschovsky, Andrew and Amy Ellen Schwartz. 1992. "Evaluating the Success of Need-Based State Aid in the Presence of Property Taxation Limitations." Public Finance Quarterly 20:4 (October), 483-498.

Tannenwald, Robert, Mark Perrault, and Frank Wattenberg. 1987. Differences in Budgetary Stress Across Massachusetts' Cities and Towns. Seventh Interim Report of the Special Commission.

Yinger, John. 1986. “On Fiscal Disparities across Cities.” Journal of Urban Economics vol. 19, 316337.

Yinger, John. 1988a. “The Fiscal Condition of County Governments in Nebraska," in Michael Wasylenko and John Yinger, eds., Nebraska Comprehensive Tax Study.

Yinger, John. 1988b. “The Fiscal Condition of Municipal Governments in Nebraska," in Michael Wasylenko and John Yinger, eds., Nebraska Comprehensive Tax Study. 
Table 1. Summary Statistics for the Variables Used in the Cost Regressions Data year is 2000 unless otherwise indicated

Number of observations $=320$

\begin{tabular}{lrr}
\hline & Average & $\begin{array}{r}\text { Standard } \\
\text { Deviation }\end{array}$ \\
\hline Measures of per capita non-school spending, FY2000-2002, & & \\
$\quad$ in FY200O dollars: & 833 & 341 \\
Adjusted non-school spending (total) & 220 & 103 \\
Public safety & 102 & 68 \\
Adjusted public works & & \\
General government, health, welfare, culture, & 164 & 84 \\
and recreation & 347 & 193 \\
Adjusted debt service, fixed cost, and other & & \\
Cost factors: & 1.38 & 2.44 \\
Population density (000s per square mile) & 9.26 & 1.10 \\
Logarithm of population & 5.83 & 4.04 \\
Percent of population in poverty, 1999 & 2.52 & 0.96 \\
Unemployment rate (percent) & 0.329 & 0.244 \\
Private jobs by place of work per resident, 2001-02 & & \\
Resources, preferences, and institutional factors: & & \\
Equalized property value per capita (000s) & 89.8 & 67.4 \\
Per capita Income (000s), 1999 & 27.5 & 8.8 \\
School-age children per capita & 0.199 & 0.029 \\
Dummy variable for mixed school system & 0.197 & 0.398 \\
Dummy variable for K-12 regional schools & 0.256 & 0.437 \\
\hline
\end{tabular}


Table 2. Estimated Coefficients in the Cost Regressions

Dependent Variables: Per Capita Non-School Spending in 2000-2002

Data year is 2000 unless otherwise indicated

Estimated coefficients (with robust standard errors below)

\begin{tabular}{|c|c|c|c|c|}
\hline $\begin{array}{l}\text { Adjusted non- } \\
\text { school spending } \\
\text { (total) }\end{array}$ & Public safety & $\begin{array}{l}\text { Adjusted public } \\
\text { works }\end{array}$ & $\begin{array}{c}\text { General } \\
\text { government, } \\
\text { health, welfare, } \\
\text { culture, and } \\
\text { recreation }\end{array}$ & $\begin{array}{l}\text { Adjusted debt } \\
\text { service, fixed } \\
\text { cost, and other }\end{array}$ \\
\hline
\end{tabular}

\begin{tabular}{|c|c|c|c|c|c|}
\hline \multirow[t]{2}{*}{ Population density (000s per square mile) } & $13.9 * * *$ & $6.00 * * *$ & 1.05 & 2.35 * & 4.47 \\
\hline & 4.6 & 1.92 & 1.02 & 1.31 & 3.40 \\
\hline \multirow[t]{2}{*}{ Logarithm of population } & $34.8 * \star \star$ & $43.3 * \star *$ & $-28.9 * \star \star$ & -1.6 & $22.0 * *$ \\
\hline & 11.7 & 5.9 & 3.5 & 2.9 & 9.4 \\
\hline \multirow{2}{*}{ Percent of population in poverty, 1999} & $14.1 * \star \star$ & 0.81 & 1.63 * & $1.65 * \star$ & $10.0 * \star \star$ \\
\hline & 3.0 & 1.17 & 0.90 & 0.72 & 2.1 \\
\hline \multirow{2}{*}{ Unemployment rate (percent) } & 39.4 ** & $23.8 * \star \star$ & 4.7 & $14.6 * \star *$ & -3.7 \\
\hline & 17.2 & 5.7 & 3.7 & 5.3 & 10.9 \\
\hline \multirow{2}{*}{$\begin{array}{l}\text { Private jobs by place of work per } \\
\text { resident, 2001-02 }\end{array}$} & $220 * \star \star$ & $68.0 * * *$ & 53.8 ** & 38.6 *** & 59.8 * \\
\hline & 48 & 25.2 & 22.0 & 13.5 & 33.0 \\
\hline \multicolumn{6}{|c|}{ Resources, Preferences, and Institutional Factors: } \\
\hline \multirow{2}{*}{ Equalized property value per capita (000s) } & $3.32 * \star \star$ & $0.80 * \star \star$ & 0.12 ** & $1.01 * \star \star$ & $1.39 * \star \star$ \\
\hline & 0.43 & 0.13 & 0.06 & 0.10 & 0.29 \\
\hline \multirow[t]{2}{*}{ Per capita Income (000s), 1999} & $6.87 \star \star$ & 1.77 ** & $1.58 * \star \star$ & 1.05 & 2.48 \\
\hline & 2.74 & 0.75 & 0.40 & 0.67 & 1.82 \\
\hline \multirow[t]{2}{*}{ School-age children per capita } & 29 & -230 & -169 & -175 & 602 * \\
\hline & 482 & 162 & 126 & 107 & 342 \\
\hline \multirow[t]{2}{*}{ Dummy variable for mixed school system } & $-62.5 * \star$ & 15.7 & $-13.6 * *$ & $15.9 * \star$ & $-80.5 * \star \star$ \\
\hline & 30.4 & 11.4 & 6.2 & 7.4 & 23.1 \\
\hline \multirow[t]{2}{*}{ Dummy variable for K-12 regional schools } & $-185 * \star \star$ & 9 & 7 & 7 & $-208 * \star \star$ \\
\hline & 27 & 10 & 9 & 6 & 19 \\
\hline \multirow[t]{2}{*}{ Constant } & -196 & $-357 \star \star \star$ & $309 * \star \star$ & 27 & -175 \\
\hline & 155 & 60 & 38 & 36 & 123 \\
\hline R-squared & 0.760 & 0.697 & 0.220 & 0.790 & 0.647 \\
\hline Number of observations & 320 & 320 & 320 & 320 & 320 \\
\hline
\end{tabular}

Notes:

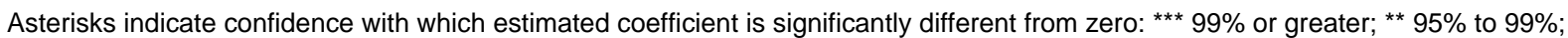
* $90 \%$ to $95 \%$.

Observations are cities and towns in Massachusetts with population greater than 1,000 other than Provincetown. 
Table 3. Summary Statistics for the Variables Used in the Residential Capacity Regressions Data year is 2000 unless otherwise indicated

Number of observations $=321$

\begin{tabular}{lrr}
\hline & $\begin{array}{r}\text { Average } \\
\text { Value }\end{array}$ & $\begin{array}{r}\text { Standard } \\
\text { Deviation }\end{array}$ \\
\hline Logarithm of per capita residential property tax levy & 6.75 & 0.46 \\
Residential capacity factors: & & \\
$\quad$ Logarithm of per capita residential value & 10.97 & 0.53 \\
Logarithm of per capita income, 1999 & 10.18 & 0.28 \\
Preferences and CIP value: & & \\
Percent of population over age 65 & 13.47 & 4.44 \\
Logarithm of average household size & 0.950 & 0.093 \\
Percent of occupied housing units that are owner-occupied & 75.4 & 13.7 \\
Logarithm of number of registered voters per household & 0.581 & 0.187 \\
Percent of Democratic voters & 0.286 & 0.095 \\
Percent of Republican voters & 0.156 & 0.052 \\
Dummy variable for municipalities with a mayor & 0.143 & 0.351 \\
Dummy variable for municipalities with town administrator & & \\
$\quad$ and representative town meeting & 0.118 & 0.324 \\
Logarithm of per capita CIP value & 9.185 & 0.716 \\
Variables in per household terms: & & \\
Logarithm of per household residential property tax levy & 7.73 & 0.47 \\
Logarithm of per household residential value & 11.9 & 0.5 \\
Logarithm of median household income, 1999 & 10.9 & 0.3 \\
\hline
\end{tabular}


Table 4. Estimated Coefficients in the Residential Capacity Regressions

Dependent Variable: Logarithm of Per Capita Residential Property Tax Levy in 2000 unless otherwise indicated

Data year is 2000 unless otherwise indicated

Estimated coefficients (with robust standard error below)

\begin{tabular}{|c|c|c|c|c|c|c|}
\hline & (1) & (2) & (3) & (4) & (5) & (6) \\
\hline Logarithm of per capita residential value & $\begin{array}{l}0.664^{* * *} \\
0.026\end{array}$ & $\begin{array}{l}0.616^{* * *} \\
0.034\end{array}$ & $\begin{array}{l}0.635^{* * *} \\
0.041\end{array}$ & $\begin{array}{l}0.720 \text { *** } \\
0.029\end{array}$ & & $\begin{array}{l}0.723 \text { *** } \\
0.037\end{array}$ \\
\hline Logarithm of per capita income, 1999 & $\begin{array}{l}0.333^{* * *} \\
0.050\end{array}$ & $\begin{array}{l}0.307^{* \star *} \\
0.053\end{array}$ & $\begin{array}{l}0.323^{* \star *} \\
0.077\end{array}$ & $\begin{array}{l}0.290 * * \\
0.045\end{array}$ & & $\begin{array}{l}0.255^{* * *} \\
0.064\end{array}$ \\
\hline Percent of population over age 65 & & $\begin{array}{l}-0.00784^{* *} \\
0.00328\end{array}$ & $\begin{array}{l}-0.00628 * * \\
0.00313\end{array}$ & & & \\
\hline Logarithm of average household size & & $\begin{array}{l}-0.411 * \\
0.216\end{array}$ & $\begin{array}{r}-0.350 \\
0.220\end{array}$ & & & \\
\hline $\begin{array}{l}\text { Percent of occupied housing units that are } \\
\text { owner-occupied }\end{array}$ & & $\begin{array}{l}0.00566^{* * *} \\
0.00128\end{array}$ & $\begin{array}{l}0.00509 * * * \\
0.00182\end{array}$ & & & \\
\hline $\begin{array}{l}\text { Logarithm of number of registered voters per } \\
\text { household }\end{array}$ & & $\begin{array}{r}-0.0499 \\
0.0539\end{array}$ & $\begin{array}{r}-0.0478 \\
0.0526\end{array}$ & & & \\
\hline Percent of Democratic voters & & $\begin{array}{r}-0.0523 \\
0.1903\end{array}$ & $\begin{array}{r}-0.0156 \\
0.2003\end{array}$ & & & \\
\hline Percent of Republican voters & & $\begin{array}{l}0.212 \\
0.266\end{array}$ & $\begin{array}{l}0.038 \\
0.259\end{array}$ & & & \\
\hline Dummy variable for municipalities with a mayor & & $\begin{array}{l}0.00847 \\
0.03275\end{array}$ & $\begin{array}{l}0.00377 \\
0.03464\end{array}$ & & & \\
\hline $\begin{array}{l}\text { Dummy variable for municipalities with town } \\
\text { administrator and representative town meeting }\end{array}$ & & $\begin{array}{r}-0.00142 \\
0.02737\end{array}$ & $\begin{array}{r}-0.00250 \\
0.02552\end{array}$ & & & \\
\hline Logarithm of population & & & $\begin{array}{l}0.0198 \\
0.0155\end{array}$ & & & \\
\hline Population density (000s per square mile) & & & $\begin{array}{l}-0.0150 \text { ** } \\
0.0062\end{array}$ & & & \\
\hline Percent of population in poverty, 1999 & & & $\begin{array}{l}0.00629 \\
0.00424\end{array}$ & & & \\
\hline Unemployment rate (percent) & & & $\begin{array}{r}-0.0206 \\
0.0135\end{array}$ & & & \\
\hline Private jobs by place of work per resident, 2001-02 & & & $\begin{array}{l}-0.140 \\
0.041\end{array}$ & & & \\
\hline Logarithm of per capita CIP value & & & & $\begin{array}{l}-0.106 \text { *** } \\
0.030\end{array}$ & & \\
\hline Logarithm of per household residential value & & & & & $\begin{array}{l}0.674^{* * *} \\
0.023\end{array}$ & \\
\hline Logarithm of median household income, 1999 & & & & & $\begin{array}{l}0.386 \text { *** } \\
0.041\end{array}$ & \\
\hline Constant & $\begin{array}{l}-3.93^{* * *} \\
0.38\end{array}$ & $\begin{array}{l}-3.05^{* * *} \\
0.42\end{array}$ & $\begin{array}{l}-3.55 \text { *** } \\
0.61\end{array}$ & $\begin{array}{l}-3.13 \text { *** } \\
0.35\end{array}$ & $\begin{array}{l}-4.55^{* * *} \\
0.38\end{array}$ & $\begin{array}{l}-3.77^{* * *} \\
0.40\end{array}$ \\
\hline R-squared & 0.858 & 0.876 & 0.882 & 0.883 & 0.872 & 0.839 \\
\hline Number of observations & 321 & 321 & 320 & 321 & 321 & 310 \\
\hline
\end{tabular}

Notes:

Asterisks indicate confidence with which estimated coefficient is significantly different from zero: *** $99 \%$ or greater; $* \star 95 \%$ to $99 \%$; * $90 \%$ to $95 \%$.

Observations are cities and towns in Massachusetts with population greater than 1,000 except in columns (3) and (6).

As in the cost regressions, we drop Provincetown from the sample in column (3).

We drop 11 cities and towns with per capita residential value $>\$ 150,000$ and per capita income $<\$ 40,000$ from the sample in column (6).

The dependent variable in column (5) is logarithm of per household residential property tax levy. 
Appendix Table A1. Prototype Communities

Data year is 2000 unless otherwise indicated

\begin{tabular}{|c|c|c|c|c|c|c|}
\hline & $\begin{array}{c}\text { Average } \\
\text { Community }\end{array}$ & $\begin{array}{c}\text { Community A } \\
\text { (Large City) }\end{array}$ & $\begin{array}{l}\text { Community B } \\
\text { (Rural Town) }\end{array}$ & $\begin{array}{c}\text { Community C } \\
\text { (Job-Center } \\
\text { Suburb) }\end{array}$ & $\begin{array}{c}\text { Community D } \\
\text { (Higher- } \\
\text { Income } \\
\text { Residential } \\
\text { Suburb) } \\
\end{array}$ & $\begin{array}{l}\text { Community E } \\
\text { (Resort Town) }\end{array}$ \\
\hline \multicolumn{7}{|l|}{ Cost Factors: } \\
\hline Population density (000s per square mile) & 1.26 & 8.00 & 0.08 & 1.50 & 0.90 & 0.24 \\
\hline Logarithm of population & 9.00 & 11.50 & 7.50 & 10.20 & 9.00 & 8.60 \\
\hline Percent of population in poverty, 1999 & 6.00 & 18.90 & 5.00 & 3.70 & 2.60 & 6.50 \\
\hline Unemployment rate (percent) & 2.61 & 4.30 & 2.70 & 1.80 & 1.20 & 2.60 \\
\hline Jobs by place of work per resident, 2001-02 & 0.37 & 0.35 & 0.20 & 1.00 & 0.22 & 0.53 \\
\hline$\triangleright$ Cost & 799 & 1,224 & 682 & 918 & 657 & 813 \\
\hline \multicolumn{7}{|l|}{ Property Tax Capacity Factors: } \\
\hline Per capita residential and open space property value & 78,786 & 23,400 & 50,500 & 70,500 & 145,500 & 250,000 \\
\hline Per capita income, 1999 & 27,233 & 17,100 & 22,900 & 35,000 & 54,000 & 28,300 \\
\hline Per capita CIP property value & 17,211 & 6,400 & 8,100 & 30,000 & 6,000 & 26,500 \\
\hline Property Tax Capacity & 1,212 & 460 & 794 & 1,403 & 1,915 & 2,493 \\
\hline Other Local Revenue Capacity & 115 & 55 & 96 & 140 & 140 & 225 \\
\hline Statutorily Required Reductions in Capacity & 650 & 250 & 525 & 915 & 1,100 & 825 \\
\hline Dapacity & 677 & 265 & 365 & 628 & 955 & 1,893 \\
\hline Non-School Cost-Capacity Gap & 122 & 959 & 317 & 290 & -298 & $-1,080$ \\
\hline
\end{tabular}

We multiply total jobs per capita in each community by the estimated coefficient on private jobs per capita.

Other local revenue capacity includes ability to raise revenue from motor vehicle excise, hotel-motel excise, urban redevelopment excise, local share of racing taxes, and state government payment in lieu of taxes for state-owned land.

Statutorily required reductions in capacity include net minimum required local contribution for schools, county taxes, charges for regional transit and regional planning authorities, and state assessments for air pollution and mosquito control. 


\section{Figure 1. Estimated Non-School Costs (Per Capita) Massachusetts Cities and Towns FY2000}

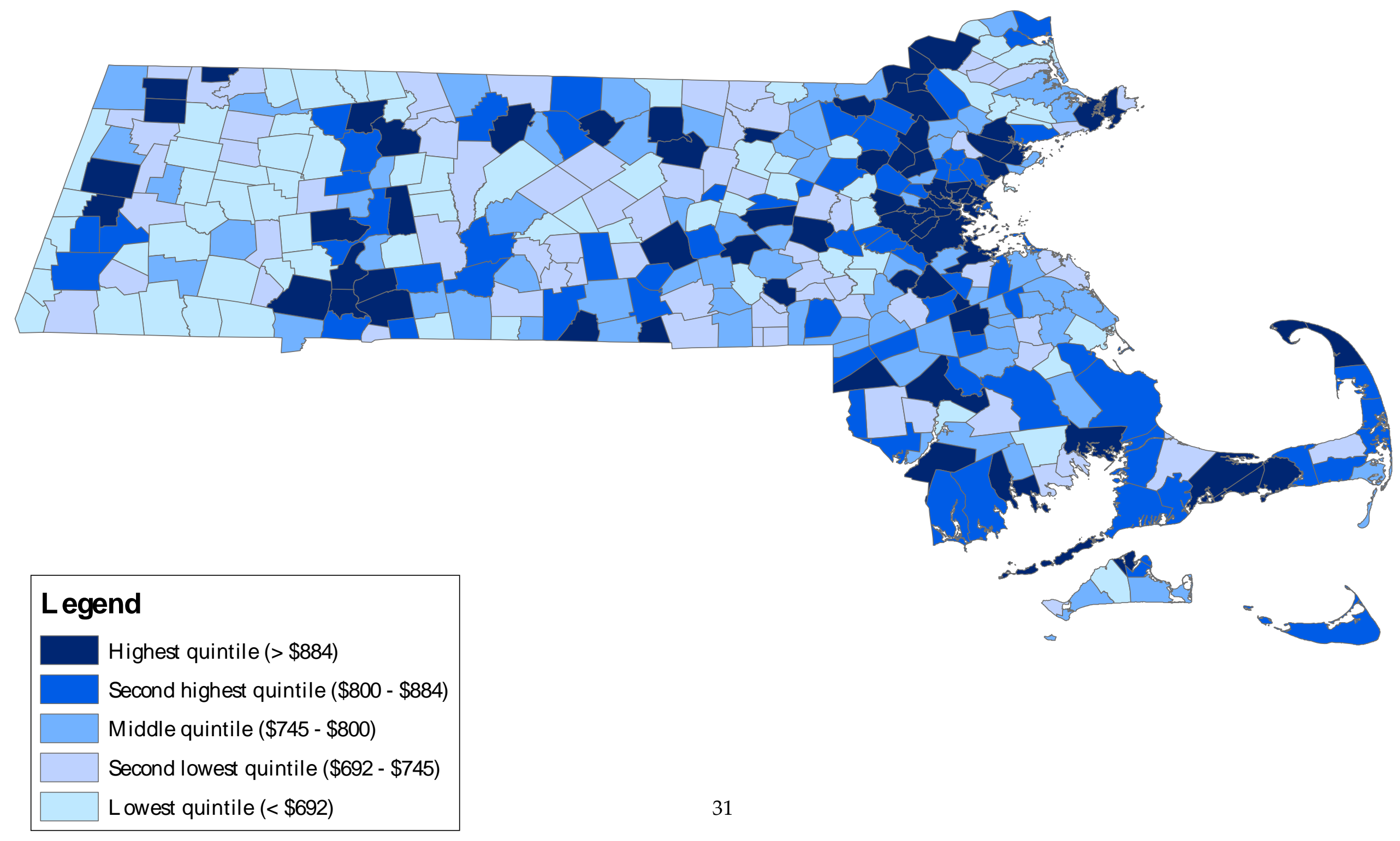




\section{Figure 2. Estimated Non-School Revenue Capacity (Per Capita)}

\section{M assachusetts Cities and Towns FY2000}

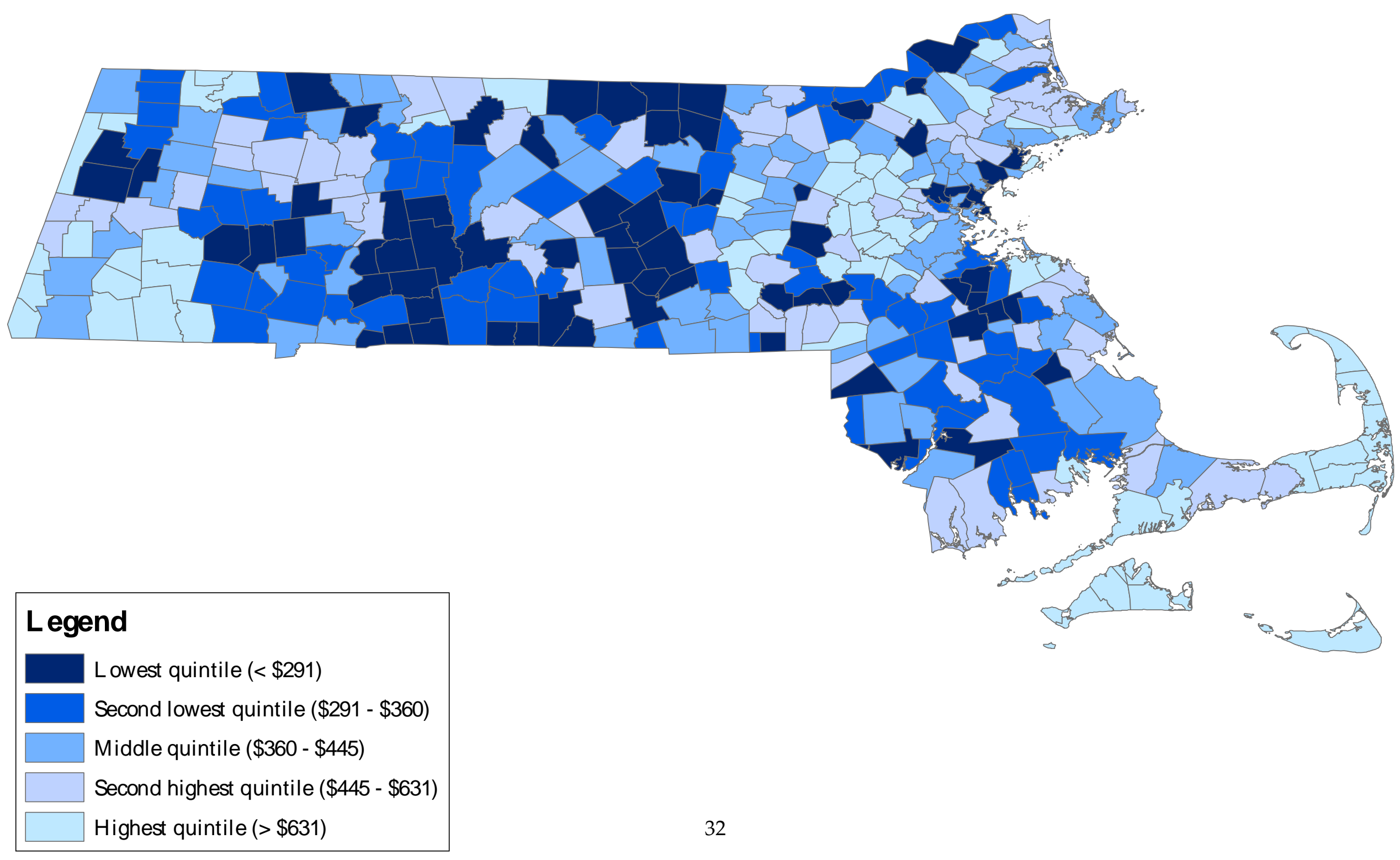




\section{Figure 3. Estimated Non-School Cost-Capacity Gap (Per Capita)}

\section{Massachusetts Cities and Towns FY2000}

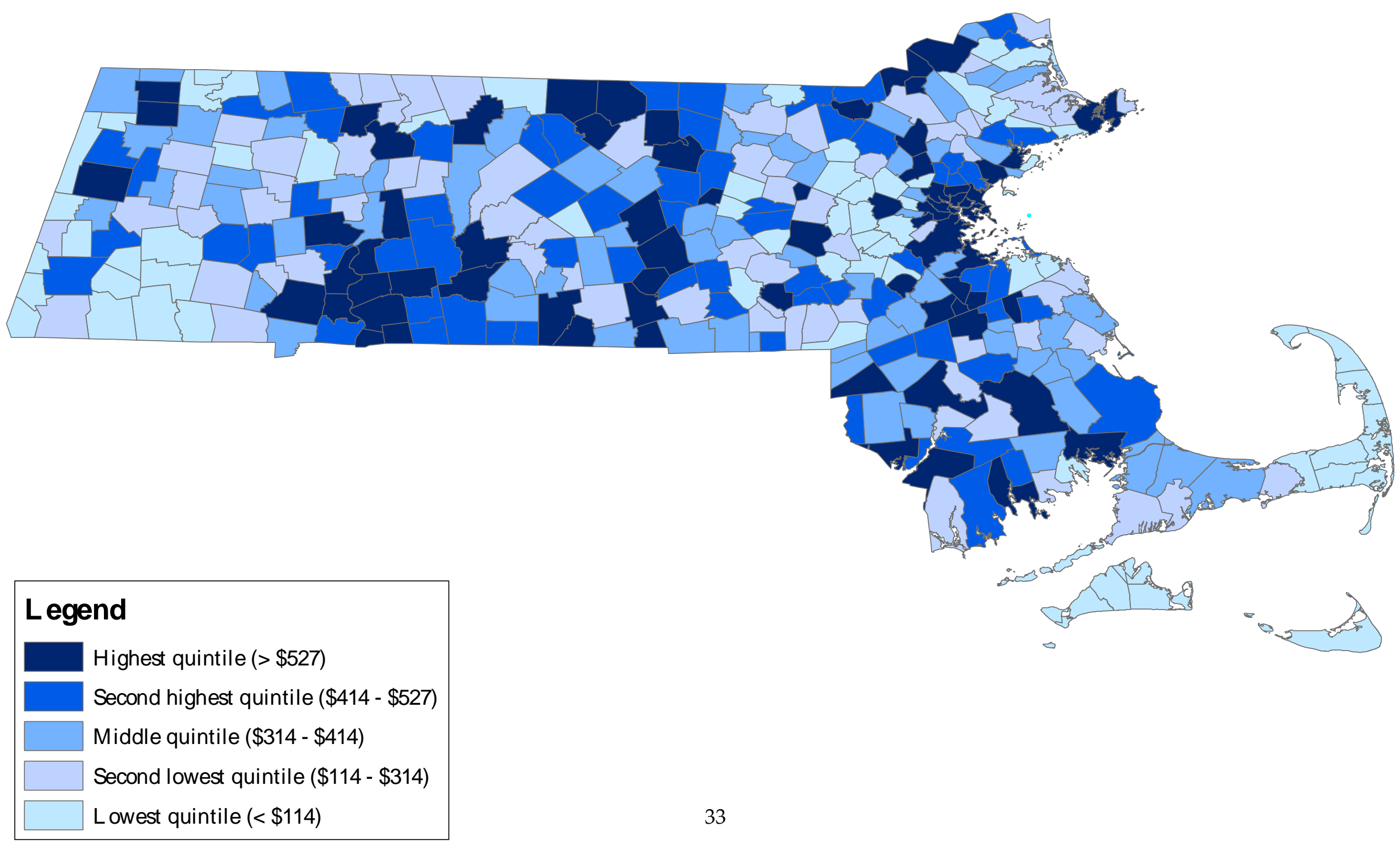

